\title{
FRICTION PROPERTIES OF PELLETS MADE OF WOOD AND STRAW
}

\author{
Adam Swietochowski, Magdalena Dabrowska, Aleksander Lisowski \\ Warsaw University of Life Sciences, Poland \\ adam_swietochowski@sggw.pl,magdalena_dabrowska@sggw.pl, aleksander_lisowski@sggw.pl
}

\begin{abstract}
The aim of the work was to obtain knowledge of the friction properties of materials subjected to pressure agglomeration (wood pellets and straw pellets). The frictional properties of the tested materials were evaluated by: the angle of internal friction and the effective internal friction angle of pellets, uniaxial shear strength, material flowability coefficient and the cohesion value of the material. Wooden pellet has a higher strength on uniaxial compression average of $36.2 \mathrm{kPa}$ than the pellet made of straw, approximately of $31.3 \mathrm{kPa}$. Based on the flowability index, it was found that straw and wood pellets are easily flowing $\left(4<f f_{c}<10\right)$. The values of the internal friction angles were higher for biomass made of wood than from straw, and were $50.02^{\circ}$ and $35.17^{\circ}$, respectively. Pellets made of straw were more cohesive materials (approximately $8000 \mathrm{~Pa}$ ) than the pellets made of wood (approximately $6600 \mathrm{~Pa}$ ).
\end{abstract}

Keywords: pellets, friction properties, cohesion, material flowability.

\section{Introduction}

The quality of densified products must meet the consumer requirements and market standards. Therefore, densified products must withstand the rigors of handling and transportation [1].

Loose materials, which include pellets, have certain mechanical properties such as: looseness, compressibility and flowability. They depend on the properties of the material such as: the shape and surface of the particles, structure of the bed and the strength of cohesion and adhesion [2-3]. These parameters allow to determine the conditions, under which the pellet ceases to be a bulk material and does not behave as a solid, but liquid [4-5]. In contrast to liquids, loose materials form dumps, which is caused by the fact that the static angle of internal friction is greater than zero. The flow mechanism of bulk materials is characterized by the fact that they can transfer shear stresses at rest. Cohesion forces between the particles are observed in cohesive materials, while these forces are notobserved in bulk materials [6].These properties play an important role in the process of loading and unloading, transporting and storage of pellets. Knowledge of the mechanical properties of granular biomass is important for the design and efficient operation of equipment for handling, storing, and processing such materials [7-9].

One of the popular and standardized methods of flowability determination is the direct shear test originally proposed by Jenike [10]. It enables the measurement of the shear strength of the material in static conditions under external load. According to the Jenike's theory of flow, the values obtained from shear tests determine the flow characteristics of the tested material and flowability parameters of loose materials with sufficient accuracy for practical application.

For this reason, the aim of this work was to obtain knowledge of the friction properties of materials subjected to pressure agglomeration (wood pellets and straw pellets). The shear tests could be a useful tool for estimation the shear resistance of wood and straw biomass for comparison of different lots of materials delivered for storage or processing.

\section{Materials and methods}

Tested materials were wood and straw pellets with a diameter of $8 \mathrm{~mm}$. Wood pellets were purchased from the Barlinek company. According to the manufacturer's declaration, they were made of $30 \%$ from sawdust from deciduous trees and $70 \%$ from sawdust from coniferous trees. Straw pellets were produced by Lootor Ltd. from wheat straw. The friction properties of pellets and their physical properties were determined before the tests.The results are summarized in Table 1.

The flowability test was carried out in accordance with the Eurocode 1 standard [11]. The tests of the internal friction angle were carried out on the modernized stand for compaction of plant material (Fig. 1).

The compaction of plant material, ejection and insertion of the drawer and bottom of the cylinder were automated.A sample of the material was poured into the cylinder of the measuring chamber with a diameter of $332 \mathrm{~mm}$ and a height of $335 \mathrm{~mm}$.In the used apparatus, shear stresses are forced by 
mutual displacement of the lower and upper rings..The displacements of the lower cylinder ring and the compaction disc were recorded using the FT 80 RLA sensor oflaser displacement from SensoPart. The shearing force and consolidation force were recorded using the CL21 force sensor from ZPWN Marki.The measurements were made after pre-consolidation of $50 \mathrm{kPa}$ until a constant density of the samples was obtained. The shear measurements were carried out at a pressure of $25 \mathrm{kPa}, 37.5 \mathrm{kPa}$ and $50 \mathrm{kPa}$, at a mutual ring sliding speed of $15 \mathrm{~mm} \cdot \mathrm{min}^{-1}$. All measurements were made in triplicate.

Table1

\section{Physical properties of pellets used for tests}

\begin{tabular}{|c|c|c|}
\hline Parameter & Wood pellets & Straw pellets \\
\hline Pellet density, $\mathrm{kg} \cdot \mathrm{m}^{-3}$ & 1213 & 1151 \\
\hline Bulk density, $\mathrm{kg} \cdot \mathrm{m}^{-3}$ & 671.1 & 587.5 \\
\hline Durability, \% & 98.31 & 94.66 \\
\hline Moisture content, \% & 3.53 & 8.52 \\
\hline Calorific value, $\mathrm{kJ} \cdot \mathrm{kg}^{-1}$ & 16785 & 13786 \\
\hline
\end{tabular}
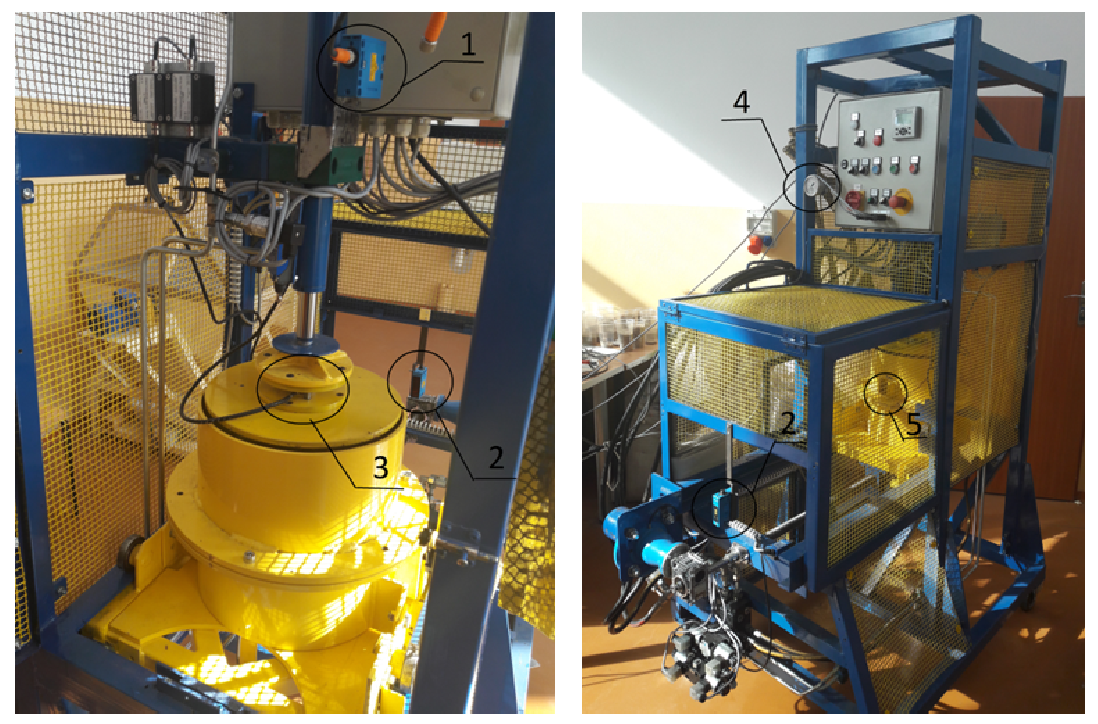

Fig. 1. View of test bench to determine angle of internal friction. 1 - sensor ofmaterial displacement by compacting piston, 2 - sensor of cylinder displacement 3 - sensorof compacting force, 4 - sensor of oil pressure in the actuator, 5 - sensorof shear force

On the basis of the obtained results, it was possible to draw two Mohr`s circles by using two normal stresses, $\sigma_{1}$ - the major principal stress at steady state flow called the major consolidation stress, and $\sigma_{c}$ - unconfined yield strength of the sample [12]. With these values a plot of $\sigma_{1}$ against $\sigma_{c}$ was obtained, and it was used to characterize the flowability of the granular material (Fig. 2).

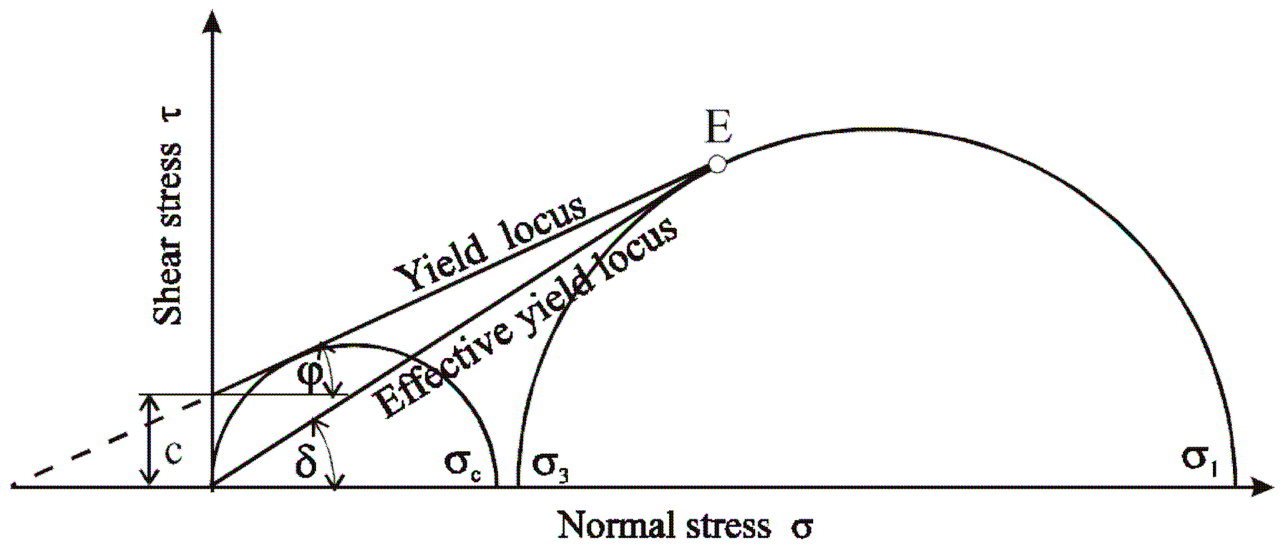

Fig. 2. Yield locus and effective yield locus [12] 
Flowability function as a relationship of the strength for uniaxial compression $\sigma_{\mathrm{c}}$ to the major principal stress $\sigma_{1}$ allows to classify loose materials in four categories in terms of their resistance shown to gravity flow: very free flowing, free flowing, average flowing and poor flowing.It was calculated from the formula:

$$
f f_{c}=\frac{\sigma_{1}}{\sigma_{c}}
$$

where $f f_{c}$ - flowability, (dimensionless),

$\sigma_{1}-$ major principal stress, MPa,

$\sigma_{\mathrm{c}}-$ strength to uniaxial compression, $\mathrm{MPa}$.

The values of the effective angle of internal friction and the angle of internal friction were determined based on the following relationships:

$$
\begin{gathered}
\varphi_{e}=\frac{\tau_{\sigma r}}{\sigma_{r}} \\
\varphi_{C}=\frac{\tau_{\sigma r}-\tau_{0.5 \sigma r}}{0.5 \sigma_{r}}
\end{gathered}
$$

where $\varphi_{e}$-effective angle of internal friction, ${ }^{\circ}$,

$\varphi_{c}$ - angle of internal friction, ${ }^{\circ}$,

$\sigma_{r}-$ consolidation stress, $\mathrm{MPa}$,

$\tau_{\sigma_{r}}-$ shear stress at consolidation stress $\sigma_{r}, \mathrm{MPa}$,

$\tau_{\sigma r}-$ shear stress at consolidation stress $0.5 \sigma_{r}, \mathrm{MPa}$.

The statistical analysis of the results was conducted using the computer program Statistica v.13.5.

\section{Results and discussion}

The results of the research in straw and wood pellets, regarding determination of the internal friction and flow friction parameters, are shown in Fig. 3, 4 and 5.

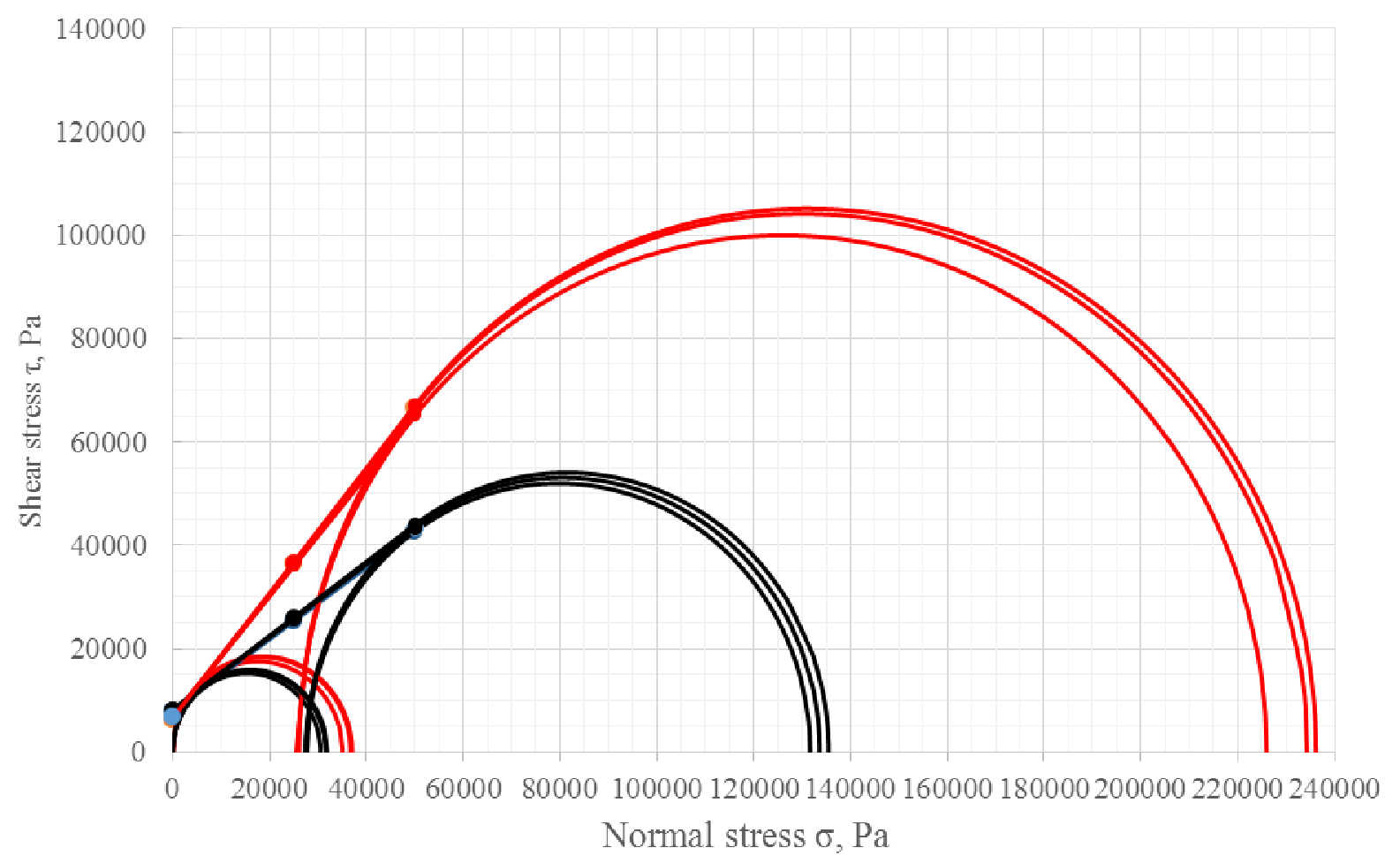

Fig. 3. Linear flow conditions for two types of pellets 
All examined parameters differed statistically significantly at the confidence level of 0.05 , depending on the type of the material. It was found that wood pellets were characterized by higher values of plasticity.Higher strength to uniaxial compression was shown by wood pellets on average about $36.2 \mathrm{kPa}$, while for straw pellets it was lower by approx. $15 \%$.

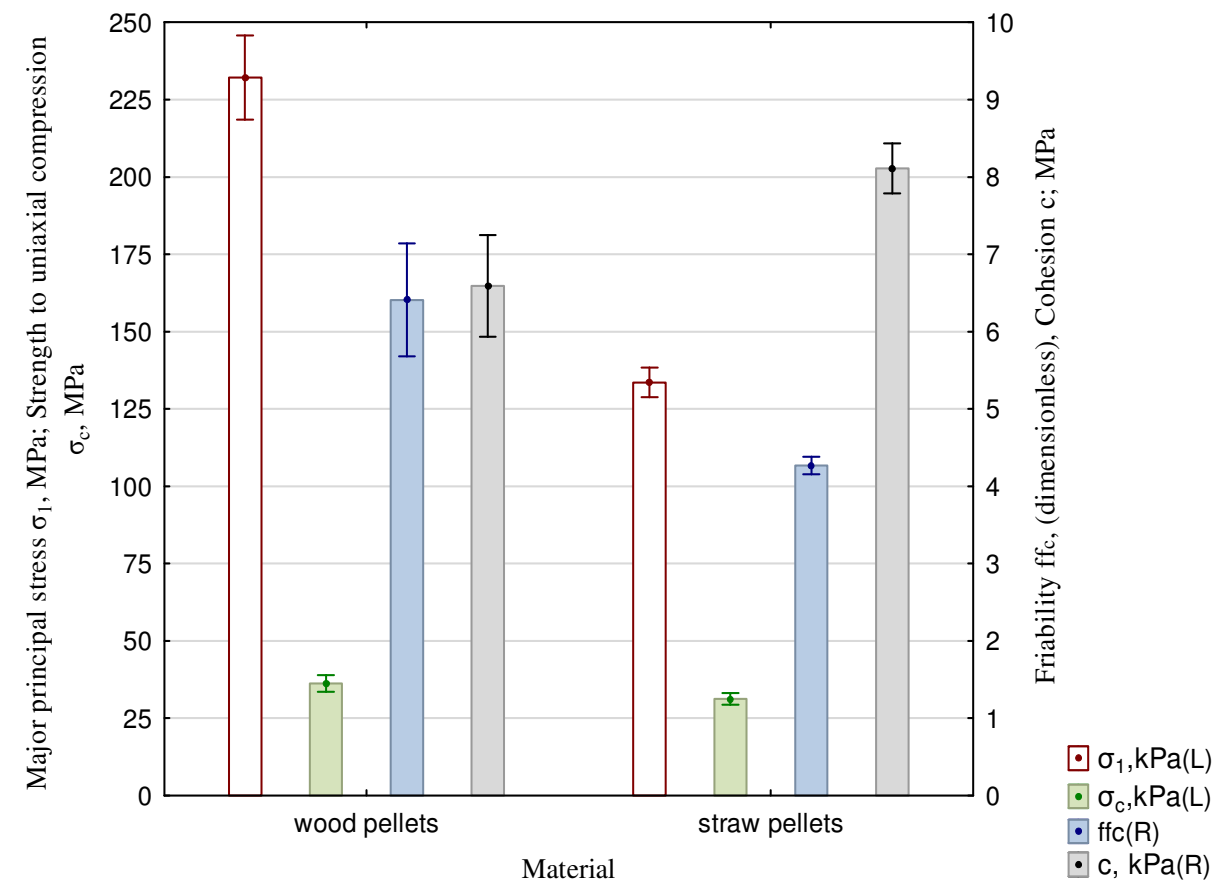

Fig. 4. Friction parameters depending on type of pellets

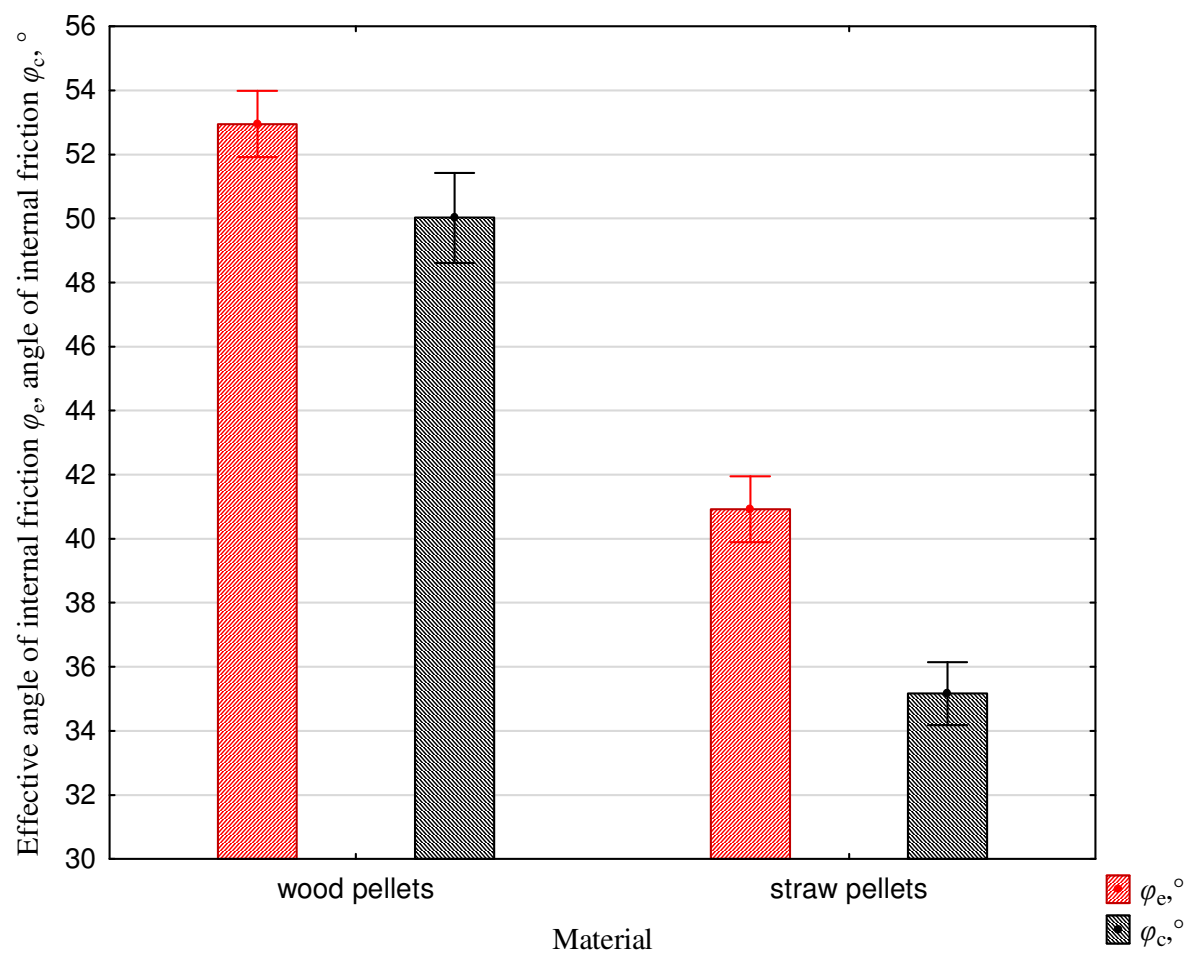

Fig. 5. Angle of internal friction and effective angle of internal friction depending on type of pellets

The straw pellet was a more cohesive material (about $8000 \mathrm{~Pa}$ ) compared to wood pellets (about $6600 \mathrm{~Pa}$ ). The higher value of the effective angle of internal friction for wood pellets $\left(50.02^{\circ}\right)$, compared to straw pellets $\left(35.17^{\circ}\right)$, indicates a rapid increase in cohesion in loose materials during consolidation. The factors that favor greater packing of particles in the agglomerate can be the external 
forces, causing the movement of particles, which is an intrinsic process during storage or forced in the transport process.

Straw pellets were characterized by a lower flowability of approx. 4.25 , and thus they can be included to more cohesive materials, compared to wood pellets (flowability rate about 6.4). Both, pellets made of wood and straw, can be included to the group of easily flowing materials. That kind of material is referred to easily flowing, when the $f f_{c}$ value is in the range of $4-10[13 ; 14]$. The flowability of the material has an impact on the material movement characteristics during the technological processes. Biomass compared to conventional fuels is less susceptible to flow material according to many authors [15-17].

\section{Conclusions}

1. Experimental methods for determining the mechanical properties should take into account the specifics of the tested materials. In case of pellets, a long distance to reach the conditions of steady flow was observed.

2. Wood pellets showed higher resistance to uniaxial compression, and it was approximately $36.2 \mathrm{kPa}$, while for straw pellets it was approximately $31.3 \mathrm{kPa}$.

3. The flowability indexes indicate that straw and wood pellets are easily flowingmaterials $\left(4<f f_{c}<10\right)$. The value of the internal friction angle was higher for the wood biomass $\left(50.02^{\circ}\right)$ and lower for the biomass from straw $\left(35.17^{\circ}\right)$.

\section{References}

[1] Kaliyan N., Morey R. Factors affecting strength and durability of densified biomass products. Biomass and Bioenergy vol. 33, 2009, pp. 337-359

[2] Peleg M. The role of water in the rheology of hydroscopic food powders. Properties of Water in Foods. Red. D. Simataos, J.L. Multon. Martinus Nijhoff Publishers Dordrecht 1985, pp. 393-404.

[3] Schubert H. Food Particle Technology. Part I: Properties of Particles and Particulate Food.Journal of Food Engineering vol. 6(1), 1987, pp. 1-32.

[4] Schwedes J. Measurement of flow properties of bulk solids. Powder Technology vol. 88, 1996, pp. 285-290.

[5] Teunou E., Fitzpatrick J. J., Synnott E. C. Characterization of food powder flowability. Journal of Food Engineering vol. 39, 1999, pp. 31-37.

[6] Molenda M. Właściwości mechaniczne sypkich agromateriałów i proszków spożywczych. Metody wyznaczania i prognoza kierunków standaryzacji (Mechanical properties of loose agromaterials and food powders. Methods of determining and forecasting standardization directions). Expertise, Lublin 2009. (In Polish).

[7] Gil M., Schott D., Arauzo I., Teruel E.: Handling behavior of two milled biomass: SRF poplar and corn stover. Fuel Processing Technology vol. 112, 2013, pp. 76-85.

[8] Guo Z., Chen X., Liu H., Lu H., Guo X., Gong X.: Effect of storage time on the flowability of biomass-coal granular system. Fuel Processing Technology vol. 125, 2014, pp. 59-66.

[9] Guo Z., Chen X., Xu Y., Liu H.: Effect of granular shape on angle of internal friction of binary granular system. Fuel vol. 150, 2015, pp. 298-304.

[10] Jenike A.W. Gravity flow of bulk solids. Bulletin No. 108 of the University of Utah, vol. 52(29), 1961.

[11] Eurocode 1. Actions on structures. Part 4. Actions in silos and tanks. EN 1991-4:2003. European Committee for Standardization, Brussels, 2003

[12] Molenda M., Horbik J. Mechanical properties of granular agro-materials and food powders for industrial practice. Part I: Characterization of mechanical properties of particulate solids for storage and handling. Lublin 2005, 155 p.

[13]Domian E., Poszytek K. 2004: Wpływ aktywności wody i konsolidacji na właściwości płynięcia wybranych typów mąki pszennej (Influence of water activity and consolidation on the flow properties of selected types of wheat flour). Acta Agrophysica vol. 4(2) 2004, pp. 259-268. (In Polish). 
[14] Kowalska J., Lenart A. Wpływ aglomeracji na właściwości ogólne wieloskładnikowej żywności w proszku(Influence of agglomeration on general properties of multicomponent powdered food). Acta Scientiarum Polonorum. Technologia Alimentaria vol. 2(2) 2003, pp. 127-36. (In Polish).

[15] Chen P., Yuan Z., Shen X., Zhang Y. Flow properties of three fuel powders. Particuology 10 2012, pp. 438-443.

[16] Chevanan N., Womac A. R., Bitra S. P., Yoder D. C., Sokhansanj S. Flowability parameters for chopped switchgrass, wheat straw and corn stover. Powder Technology vol. 193 2009, pp. 79-86.

[17] Guo Q., Liu H., Chen X., Li S., Guo X., Gong X. Research on the flow properties of the blended particles of rice straw and coal. Fuel vol. 102 2012, pp. 453-459. 